\title{
Ozone in medicine
}

\author{
Konrad Michalski1 ${ }^{1, A-C} \oplus$, Małgorzata Majka Kulińska-Michalska2,D-F® \\ ${ }^{1}$ Private Medical Cabinet \\ ${ }^{2}$ Medical University in Lodz Clinic of Oral and Periodontal Mucosa Diseases \\ A - Koncepcja i projekt badania, B - Gromadzenie i/lub zestawianie danych, C - Analiza i interpretacja danych, \\ D - Napisanie artykułu, E - Krytyczne zrecenzowanie artykułu, F - Zatwierdzenie ostatecznej wersji artykułu \\ Michalski K, Kulińska-Michalska M. M. Ozone in medicine. Med Og Nauk Zdr. 2019; 25(3): 135-137. doi: 10.26444/monz/111999
}

\begin{abstract} used. pain reduction.

\section{Key words}

ozone, ozone therapy, dentistry

\section{INTRODUCTION}

Ozone was discovered in 1840 by Christian Friedrich Schönbein [1]. However, the first use of ozone is dated 1870 by Landler [2]. Ozone is an allotropic form of oxygen. It is a blue gas with very strong oxidizing properties. Ozone is an unstable, non-flammable compound that dissolves well in water. It is used in the disinfection of drinking water and closed spaces (ozonation), but it is also increasingly used in medicine due to, its activity as a antiviral, antifungal and antimicrobial agent. Thanks to the benefits of ozone therapy, it is used, among others, in dentistry, dermatology, orthopedics, surgery, gynecology and ophthalmology.
\end{abstract}

Introduction and objective. Ozone is an allotropic form of oxygen. Thanks to its properties, it is increasingly used in medicine. The aim of the study is to define the properties of ozone therapy and the areas of medicine in which it can be

Brief description of the state of knowledge. Currently, ozone therapy is used as a therapy complementary to a basic treatment. In medicine, it is used to achieve a disinfecting and immunostimulating effect, with an additional advantage of

Conclusions. Numerous studies confirm the effectiveness of ozone in many areas of medicine with multiple benefits. In this review, the mechanism of ozone therapeutic action and indications for its application are discussed.

\section{OBJECTIVE}

The aim of the study was to specify the properties of ozone therapy, as well as list the areas of medicine in which this therapy has been applied.

\section{THE USE OF OZONE IN MEDICINE}

Ozone is one of the strongest oxidants. It reacts with organic compounds causing their oxidation. This leads to the destruction of bacterial cell walls, lipid peroxidation, while the final stage is depolarization of the cell membrane and loss of enzymes and transport proteins. Thanks to these properties, ozone achieves a disinfectant effect $[3,4]$. The effect on the immune system is achieved by stimulating the proliferation of immunocompetent cells, immunoglobulins and increasing the activity of macrophages. In addition, ozone triggers increased oxygen absorption in the lungs and increases transmembrane flow. Analgesic effects are achieved

Address for correspondence: Małgorzata Majka Kulińska-Michalska, Medical University in Lodz Clinic of Oral and Periodontal Mucosa Diseases

E-mail: malgorzatakulinskam@gmail.com

Received:21.01.2019; Accepted: 28.08.2019 by promoting the secretion of vasodilators, among others, NO that expands arterial and venous walls $[3,4,5,6]$. The use of ozone therapy includes the ozone-oxygen mixture with a maximum concentration of 5\% ozone and $95 \%$ oxygen.

The main forms of ozone use: the most commonly used form of therapy (the possibility of using open and closed systems) [7] water (ozonation of drinking water, water in swimming pools). The study shows that ozonated water is more effective against nosocomial infections caused by Enterococcus than $\mathrm{NaOCl}[8,9,10]$, and ozonated oil preparations are used effectively in the treatment of skin infections.

Dental procedures in which ozone is used:

- prevention and treatment of carious lesions, especially initial stages;

- treatment of infectious diseases of mucous membranes;

- disinfection of root canals;

- marginal periodontal disease treatment;

- increased dentin sensitivity prevention;

- disinfecting the work field (implantology, prosthetics, dental surgery);

- stopping the bleeding.

Myśliwiec et al. conducted a study in which they showed that ozone therapy administrated in patients after extraction of a molar, reduces the amount of pain related complications [11].

A recent study has demonstrated that the effectiveness of ozone therapy in combination with $\mathrm{NaOCl}$ in combating E. faecalis during endodontic treatment is comparable to a temporary antiseptic dressing [12]. In endodontics, ozone therapy is primarily used to sterilize the canal system. During repeated endodontic treatment with antibiotic-resistant strains, the effectiveness of the therapy can be increased by using ozone. Research shows that ozone is effective against Streptococcus mutans, Candida albicans and Staphylococcus aureus [13]. Researchers show that the use of ozonated water to disinfect prostheses can limit the growth of C. albicans [14]. Khatri et al. in their study on a group of 40 patients with 
oral candidiasis, demonstrated a higher efficacy of ozone water compared to Clotrimazole therapy. [15]

The most important application of ozone is the field of conservative dentistry. The procedure for treating carious lesions is painless and non-invasive. In the case of early carious lesions, the therapy is based on the application of ozone and then the use of remineralizing substances. Due to its ability to open dentinal tubules and facilitate the diffusion of calcium and phosphorus ions, it is used in cervical hypersensitivity [16]. In deep caries leasions, the use of ozone is as an additional therapy to facilitate primary treatment and does not replace invasive methods in cavity preparation. [17]

Ozone therapy is also used in periodontics with dedicated profiled tips to allow optimal access into the periodontal pockets and precise ozone applications. Nagayoshi et al. demonstrated the high efficiency of ozone water in the treatment of Gram (-) and Gram (+) bacteria [8]. Szkutnik et al. conducted a study on a group of patients with periodontal and mucous membrane diseases (aphthae, cold sores, candidiasis, lichen planus, gingivitis and periodontitis), which showed that in $61 \%$ a positive effect of the treatment in the form of clinical improvement and pain reduction; exceptionally good results were obtained in patients with herpes labialis [18].

Ozone therapy is contraindicated in the following conditions:

- pregnancy

- severe anaemia and myasthenia

- active bleeding

- recent heart attack

- asthma

- epilepsy

- pacemaker $[19,20]$.

Ozone toxicity depends on the route of exposure and concentration. If the maximum dose of ozone is exceeded, adverse effects such as irritation of the upper respiratory tract, coughing, headache, nausea or vomiting may occur $[19,20]$. However, water ozonation leads to the oxidation of bromides and the formation of dangerous and carcinogenic bromates [21].

Various protocols and techniques of ozone therapy have found their application in orthopedics and traumatology. Ozone is used in open and closed bone and soft tissue injuries, early septic complications after surgery, chronic inflammation of bones and joints, post-traumatic states of circulatory system disorders, hard-to-heal wounds, secondary bacterial, viral and fungal infections [22, 23].

Studies show that ozone therapy may normalize blood glucose and other metabolites in diabetic patients. An additional benefit is the reduction of diabetic complications $[24,25,26]$. Campanati et al. conducted a study on a group of 195 patients with diagnosed second-degree skin burns, which were monitored over 12 weeks. The subjects were divided into two groups in which the effectiveness of using ozonated oil preparations and hyaluronic acid was compared. Researchers have shown that the effectiveness of treatment ozone therapy in skin burns is comparable to standard hyaluronic acid. It has also been noted that ozone preparations reduce the number of postoperative hyperpigmentation [27].

\section{CONCLUSIONS}

Many studies confirm positive effects of ozone therapy and its various applications in medicine. Particularly of note are disinfecting and immunostimulating properties, as well as the fact that ozone therapy is classified as minimally invasive. If the protocol is followed, it is safe to use. There is growing body of literature describing the use of ozone therapy in medicine; however, further research is necessary to establish specific protocols for ozone management and the possibilities of its application.

\section{REFERENCES}

1. Seaverson K, Tschetter D, Kaur T. Patient guide to oxygen/ozone therapy. Health centered cosmetic dentistry. Cited 2010 January 13.

2. Pietrzycka K. Ozon w endodoncji, e-Dentico 2007;3: 54-58.

3. Seidler V, Linetskiy I, Hubalkova H, Staňkova H, Šmucler R, Mazanek J. Ozone and Its Usage in General Medicine and Dentistry. A Review Article. Prague Medical Report. 2008; 109(1): 5-13.

4. Teresa B, Wolanska E, Cieszko-Buk M, Orlowski M, Chalas R.Practical use of ozone in dentistry - comments. Annales Universitatis,Maria Curie-Sklodowska Lubin-Polonia. 2008; VOL. LXIII, N 1, 28.

5. Seidler V, Linetskiy I, Hubalkova H, et al. Ozone and its usage in general medicine and dentistry-a review article. Prag Med Rep. 2008; 109: 5e13.

6. Bhateja S. The miraculous healing therapy e "Ozone therapy" in dentistry. Indian J Dent. 2012; 3(3): 150-155.

7. Nogales CG, Ferrari PH, Kantorovich EO, Legw-Marques J. Ozone therapy in medicine and dentistry. J Contemp Dental Pract. 2008; 9: 1-9.

8. Nagayoshi M, Kitamura C, Fukuizumi T, Nishihara T, Terashita M. Antimicrobial effect of ozonated water on bacteria invading dentinal tubules. J Endod. 2004; 30: 778-781.

9. Azarpazhooh A, Limeback H. The application of ozone in dentistry: a systematic review of literature. J Dentist. 2008; 36: 104-116.

10. Skalska K, Ledakowicz S. Rozwój dezynfekcji chemicznej-perspektywy wykorzystania ozonu. Laboratorium 2007; 10, 10-13.

11. Myśliwiec L, Wiśniewska I, Sporniak-Tutak K. Zastosowanie ozonoterapii jako jedna $\mathrm{z}$ metod zapobiegania powikałniom zapalnym po operacyjnym usunięciu zębów trzecich trzonowych w żuchwie doniesienia wstępne. Annales Academiae Medicae Stetinensis 2007; 53(3): 94-97.

12. Bitter K, Vlassakidis A, Niepel M, Hoedke D, Schulze J, Neumann K, Moter A, Noetzel J. Effects of Diode Laser, Gaseous Ozone, and Medical Dressings on Enterococcus faecalis Biofilms in the Root Canal Ex Vivo, Biomed Res Int. 2017.

13. Oizumi M, Suzuki T, Uchida M, Furuya J, Okamoto Y. In vitro testing of a denture cleaning method using ozone. J Med Dent Sci. 1998; 45: $135-139$.

14. Arita M, Nagayoshi M, Fukuizumi T, et al. Microbicidal efficacy of ozonated water against Candida albicans adhering to acrylic dentures plates. Oral Microbiol Immunol. 2005; 20: 206-210.

15. Khatri I, Moger G, Kumar NA. Evaluation of effect of topical ozone therapy on salivary Candidal carriage in oral candidiasis. Indian J Dent Res. 2015; 26(2): 158-62. doi: 10.4103/0970-9290.159146.

16. Bachanek T, Orłowwski M, Wolańska E, Cieszko-Buk M. Ozon w stomatologii - uwagi praktyczne. Medicus 2005,6.

17. Tanasiewicz M, Próchnica zębów, ISBN 978-83-61190-12-7, 103-110.

18. Szkutnik J, Sieczkarek J, Wysokińska-Miszczuk J. Skuteczność ozonoterapii wybranych przypadków chorobowych tkanek przyzębia i błony śluzowej jamy ustnej - doniesienie wstępne. Ann Acad Med Stet. 2007; 53, Suppl. 3: 145-15.

19. Bocci V, Borrelli E, Travagli V, Zanardi I. The ozone paradox: ozone is a strong oxidant as well as a medical drug. Med Res Rev. 2009; 29: 646-682.

20. Bocci V. Is it true that ozone is always toxic? The end of a dogma. Toxicol Appl Pharmacol. 2006; 216: 493-504.

21. Michalski R, Łyko A. Uboczne nieorganiczne produkty dezynfekcji wody. Problemy i wyzwania. Inżynieria i Ochrona Środowiska. 2012; 15(4): 353-364.

22. Białoszewski D, Kowalewski M. Przydatność miejscowych, głębokich insuflacji mieszaniną ozonowo-tlenową w profilaktyce i leczeniu zakażeń w obrębie narządów ruchu. Ortop Traum Rehab. 2001; 3(4): 552-556. 
23. Białoszewski D, Nowak P, Michalski P. Przydatność terapii ozonem w leczeniu przewlekłych i pourazowych patologii w obrębie narządu ruchu. Ortop Traum Rehab. 2000; 4: 47-49.

24. Al-Dalain SM, Martınez G, Candelario-Jalil E, Menéndez S, Re L, Giuliani A, León OS. Ozone treatment reduces markers of oxidative and endothelial damage in an experimental diabetes model in rats. Pharmacol Res. 2001; 44(5): 391-396.

25. Martinez G, Al-Dalain SM, Menendez S, Guiliani A, Leon OS. Ozone treatment reduces blood oxidative stress and pancreas damage in a streptozotocin-induced diabetes model in rats. Acta Farm Bonaerense 2005; 24(4): 491.
26. Martínez-Sánchez G, Saied M, Al-Dalain, Menéndez S, Re L, Giuliani A, Candelario-Jalil E, Álvarez H, Fernández-Montequín JI, León OS Therapeutic efficacy of ozone in patients with diabetic foot. Eur J Pharmacol. 2005; 523(1-3): 151-161.

27. Campanati A, De Blasio S, Giuliano A, Ganzetti G, Giuliodori K, Pecora T, Consales V, Minnetti I, Offidani A. Topical ozonated oil versus hyaluronic gel for the treatment of partial- to full-thickness second-degree burns: A prospective, comparative, single-blind, nonrandomised, controlled clinical trial. Burns 2013; 39(6): 1178-1183.

\title{
Ozon w medycynie
}

\begin{abstract}
Streszczenie
Wprowadzenie. Ozon jest formą alotropową tlenu. Jest niebieskim gazem o bardzo silnych właściwościach utleniających. To związek nietrwały, niepalny, który dobrze rozpuszcza się w wodzie. Używa się go do wyjaławiania wody pitnej oraz pomieszczeń (ozonowanie), jednak coraz większe zastosowanie znajduje również w medycynie, gdzie cenione jest przede wszystkim za swoje działanie wiruso-, bakterio- i grzybobójcze. Dzięki korzyściom, jakie niesie terapia ozonowa, jest ona wykorzystywana m.in. w stomatologii, dermatologii, ortopedii, chirurgii, ginekologii czy okulistyce.

Cel pracy. Celem pracy było wskazanie właściwości ozonoterapii i dziedzin medycyny, w których można ją zastosować. Skrócony opis stanu wiedzy. Obecnie ozonoterapia stosowana jest jako terapia uzupełniająca leczenie podstawowe. W medycynie wykorzystuje się jej działanie dezynfekujące, immunostymulujące, dodatkową jej zaletą jest zredukowanie dolegliwości bólowych w trackie leczenia.

Podsumowanie. Liczne prace naukowe potwierdzają skuteczność zastosowania ozonu w wielu dziedzinach medycyny. W większości przypadków terapia ozonowa stosowana jest jako terapia uzupełniająca. Z uwagi na wiele korzyści, jakie niesie zastosowanie ozonu, przy braku działań niepożądanych, terapia ta winna być szerzej rozpowszechniona. W artykule przedstawiono mechanizm działania terapii ozonowej oraz wskazania do jej zastosowania.
\end{abstract}

\section{Słowa kluczowe}

stomatologia, terapia ozonowa 